\title{
Efforts to Increase Interest in Writing Educational Research Proposals through the Development of 6 KKNI Assignments
}

\author{
Elfitra $^{1}$, M.Badzlan Darari ${ }^{2}$ and Erlinawaty Simanjuntak ${ }^{3}$ \\ \{elfitra@unimed.ac.id ${ }^{1}$ \} \\ Departmen Mathemathic and Science, State University of Medan, Sumatera \\ Utara,Indonesia ${ }^{1,2,3}$
}

\begin{abstract}
The KKNI as a curriculum that has been implemented in Unimed is a manifestation of the quality and identity of the nation in learning with a quality and productive national education system. The main objective of this study is to increase students interest in writing educational research proposals through the development of 6 tasks in our curriculum. And also the relationship between Cjrs tasks, CB ideas and engineering. This research is a descriptive research. The sample taken is the fifth semester students of the first semester who manage the study program. Data retrieval is done by questionnaire and analysis of task results. The results of the questionnaire calculation at the beginning were only 9 people (30\%) students who had a high grade to discuss the research proposal. At the end of the meeting, 6 questionnaires showed an increase in interest to 24 people $(80 \%)$. From the results of the questionnaire calculation at the beginning, only 9 people $(30 \%)$ students had a high interest to discuss research proposals. At the end of the meeting, 6 questionnaires showed an increase in interest to 24 people $(80 \%)$
\end{abstract}

Keywords: writing, educational research, KKNI

\section{$1 \quad$ Introduction}

The Indonesian National Qualification Framework (IQF/KKNI) is a qualification framework for Indonesian human resources that juxtaposes, equates and integrates the education sector with the training sector and work experience in a work ability recognition scheme that is tailored to the structure in various occupational sectors. The KKNI is an embodiment of the quality and identity of the Indonesian nation in relation to the national education system, the national job training system, and the national equivalence learning outcomes assessment system, which is owned by Indonesia to produce quality and productive national human resources.

The qualification description at each level of KKNI comprehensively considers a complete learning achievement, which can be produced by an educational process both formal, non-formal, informal, and independent experience to be able to do quality work. Learning outcomes also include aspects of national identity development which are reflected in the Pancasila, the 1945 Law and Unity in Diversity, namely upholding the five principles of 
Pancasila and upholding the law and upholding a commitment to respect the diversity of religions, ethnicities, cultures, languages and arts grow and develop on the earth of Indonesia.

Be advised that papers in a technically unsuitable form will be returned for retyping. After returned the manuscript must be appropriately modified.

Medan State University (Unimed) is one of the universities in North Sumatra that has implemented its learning curriculum with KKNI in accordance with national instructions in the Minister of Culture and Regulation (Permendikbud) number 73 of 2013 concerning the application of the KKNI in the Higher Education field. The Unimed KKNI learning curriculum is supported by the six assignments that students must work on for one semester. The six assignments are Routine Assignment (TR), Criitical Book Review (CBR), Critical Journal Review (CJR), Mini Research (MR), Engineering Ideas (RI) and Project Assignments. These six assignments are intended so that students become human beings who are skilled with science and have competence in their fields.

Many benefits can be obtained in the implementation of sixassignmentsKKNI. Simply put if students are able to review journals and criticize journals students are expected to be able to analyze the needs of steak holders based on the findings ofthe researchers. From the results of the analysis made by the students, with the guidance of the student lecturers making this mini research, the results of the problem solving process were generated.

During this time the work done by students was limited to working on questions, creating papers and assignment reports that were only presented in front of the class. Though many of these assignments can be continued into a mini research that can be published. However, students tend to prefer to talk than do research. hal senada juga diutarakan rahmiati (2014) mengenai minat menulis mahasiswa. To conduct a mini research, a preparation is needed systematically in a research proposal. For students in writing research proposals, the biggest problem is the lack of ability or willingness of students to write. Very few students have an interest in writing research proposals, as seen from the low interest of students participating in PKM. Lack of reference, motivation and time is also a problem that most students complain about when asked to design a research proposal and conduct research.

The role of learning tools in the KKNI curriculum is very important to overcome them. Each assignment of the six main KKNI assignments is directed to find the sub-section of the learning objectives. In the research methodology course, students are expected to not only be able to write a research proposal as a requirement for graduating courses. Through the development of sixKKNI assignments that are applied to learning and the synergy of the entire KKNI assignment, it is expected to encourage students' interest in making research proposals to carry out research. And it is also expected that the results of the research will trigger motivation to publish the results of research in the form of articles.

In the course of the KKNI implementation, several previous studies to develop learning tools have been carried out such as the development of KKNI-based textbooks by Tiur malasari (2017), Development of KKNI-oriented learning tools in Islamic Economics courses by Tri Effyanti (2018). Learning outcomes can be in the form of scientific work produced by students can also improve the competitiveness of universities as studied by Rudi Salam, et al (2017) with the title of research "Improving the Quality of Scientific Publications in Supporting Higher Education Competitiveness"

\section{Literature Review \\ 2.1 The KKNI}

The KKNI is a reference framework that is used as a measure in the recognition of education levels. The KKNI is also referred to as a competency qualification framework that 
can pair, equalize, and integrate between education and job training as well as work experience in the framework of providing recognition of work competencies in accordance with the work structure in various sectors (dokumen 001)

According to Perpres No. 08 of 2012, the KKNI is an embodiment of the quality and identity of the Indonesian nation in relation to the national education and training system owned by Indonesia. So, it can be concluded that the KKNI is a study program that requires the education system in Higher Education to clarify the profile of its graduates, so that it can be adapted to suitability in the perspective of community needs analysis.

Implementation of curriculum based on KKNI in Higher Education is needed because it can hone the potential of students to become agents who are broad-minded and have skills that are in accordance with the criteria needed in the community. In addition, the KKNI system makes it easier for universities to determine the ultimate goal as a result of the learning outcomes that have been taught.

Thus, the implementation of the KKNI makes students create more for various things. To improve the quality of university graduates, both lecturers and students must be able to participate in the implementation of KKNI curriculum.

\subsection{Definition of Research}

Research is an activity to search, record, formulate and analyze until compiling the report. A scientific research based on scientific characteristics namely rational, empirical and systematic. Here are some research terms according to some experts:

a. David H. Penny ;Research is a systematic thinking about various types of problems the solution requires the collection and interpretation of facts.

b. J. Suprapto MA ;Research is the investigation of a field of science that is carried out to obtain facts or principles patiently, carefully and systematic.

c. Sutrisno Hadi MA ;In accordance with its objectives, research can be defined as an effort to find, develop and test the truth of a knowledge.

d. Mohammad Ali ; Research is a way to understand something through investigation orthrough the search for evidence that emerged in connection with the problem, which done carefully so that the solution is solved.

Type of educational research based of the method

a. Historical research

b. Ex post facto research

c. Experimental research

d. Survey research

e. Evaluation research (evaluation research)

f. Policy research

g. Naturalistic research

h. Action research

i. Research development

According to the type of data and analysis, educational research is divided into:

a. Quantitative research

b. Qualitative research

c. Quantitative and qualitative combined research

According to the depth of analysis of research data

a. Descriptive research 


\section{b. Explanatory research}

According to the level of explanation (explanation)
a. Descriptive research
b. Correlational research (relationship)
c. Comparative research

According to the place of research

a. Field research (field research)

b. Library research (library research)

c. Laboratory research (laboratory research)This section must be in one column.

In Narbuko, etc (2012) and Sandjaja ( 2011)

Several stages that must be passed by theresearcher are as follows ( Suryana,2010)

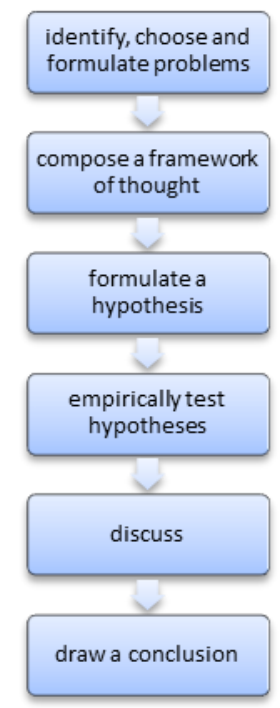

Fig. 1: research steps implementation

In educational research, the first stage that must be prepared in the study is arranged in a planned manner in the form of a research proposal (stage 1 to 3 ).

\subsection{Ability to write a Research Proposal}

\subsubsection{Writing Ability}

Writing is a creative process of moving ideas into writing symbols. More specifically explained that writing has three main aspects, namely the goals to be achieved, the ideas to be communicated, and the idea transfer system. In line with this explanation, (Akhdiah, 2003) 
argues "writing ability is a complex ability, which demands a number of knowledge and skills."

The writing consists of a series of meaningful letters. In written communication there are at least three elements involved, namely the author as the messenger of the message or the content of the writing, channel or medium of writing, and the reader as the recipient of the message.

(Rahayu, 2007) explains more specifically, scientific writing concerns the language aspect. Language narration must be complete and complete, complete, solid, clear, concise, and strong / impressive. So, the writing has communicative disclosure techniques and shows a rational frame of mind. Writing activities are very concerned with the elements of mind, reasoning, and factual data because that is the form that results from writing activities in the form of scientific writing or nonfiction.

Based on the opinions of the experts above, it can be concluded that writing is a form of indirect communication by utilizing graphology, language structure and vocabulary so as to produce coherent, expressive and understandable writing to express ideas, thoughts, or ideas to others. Writing skills require experience, time, opportunity, and practice. Through practice and practice continuously and regularly will improve writing skills.

\subsubsection{Writing Educational Research Proposals}

A proposal is a plan that is prepared for a particular activity or it can also be said as a plan that is outlined in the form of a work plan (Hasnun 2004). Proposals are notified with expectations and requests. Therefore, in a proposal clearly explained what is planned and needed. To be more convincing to the reader, sometimes a proposal is equipped with pictures, photos, activity schedules, maps, graphics or other things needed so that the reader knows and understands the activities that will be carried out.This section must be in two columns.

Interesting proposals will attract people to read them. If the interested person is really interested, then this is the success of proposal writing. The purpose of proposal writing can vary. Among them is to get approval and get funding and facilities assistance (Hasnun, 2004).

In general, the following are proposals commonly proposed by people (Susanto, 2010)

a. Business proposal (business establishment proposal)

b. Project proposal (proposal for submission of funds to donor agencies)

c. Research proposal (thesis, thesis and dissertation proposal)

d. Activity proposals (proposals for seminars, training and competitions)

\section{$3 \quad$ Research Methods}

According to Moh Nazir (2011), the scope of the research method is the techniques and procedures used in the study. Therefore, the determination of research methods is closely related to the tools and steps of research work.

This research is a descriptive study, which is the research that analyses the data only to the variable description one by one. Description means giving systematically and factually about certain characteristics in a particular population. According to Sukmadinata (2006), explaining descriptive research is a form of research aimed at describing existing phenomena, both natural 
phenomena and man-made phenomena ".The copyright form is located on the authors' reserved area.

The learning model applied is discovery learning. Discoveryis a learning model developed based on the view of constructivism. This model emphasizes the importance of understanding structures or important ideas for a discipline, through active involvement of students in the learning process. According to Bruner in Winataputra (2003) meaningful learning can only occur through discovery learning. In order for learning to be meaningful and have a strong information structure, students must actively identify the key principles that they find themselves, not just accept explanations from the teach

The subject of this research was the fifth semester mathematics education students who took the research methodology courses, namely the mathematics education extension class as many as 30 people.

The instrument in this study is a questionnaire to measure student interest in writing proposals and analyzing 6 synergistic KKNI assignments.

\section{Result And Dicussion}

This study only lasted for 6 meetings with the ultimate goal that students have a high interest in writing proposals and producing proposals at the 6th meeting through the development of KKNI assignments.

This research was conducted through several stages of activities accompanied by giving questionnaires to measure and increase student interest in writing research proposals. Furthermore, the data is integrated into a research result.

In the early stages students are encouraged to be able to study independently while still receiving intensive guidance from lecturers. Students are introduced to the material and the ultimate goal of learning. Interaction is done to see the characteristics of students. In addition, before learning is carried out students are given a questionnaire to indicate students' interest in writing proposals. Some indicators that are seen to measure student interest are (1) concentration of attention (2) personal experience (3) motivation to write (4) motivation to read (5) general knowledge (6) emotions in expressing thoughts. Questionnaire consists of 23 positive statements (interested) and 18 negative statements (not interested).

The questionnaire is given at the first learning meeting after getting a college contract. The students emphasized that giving questionnaires did not affect the final score. From the raw score, the results of the questionnaire at the beginning of the meeting were obtained as follows

Table 1. Interest Questinnare results I

\begin{tabular}{ccc}
\hline Interest critria & $\mathbf{f}$ & $\%$ \\
\hline Very high & 0 & 0 \\
High & 9 & 30 \\
Sufficient & 14 & 46,6 \\
Low & 7 & 23,3 \\
Very low & 0 & 0 \\
\hline
\end{tabular}


From the data above shows the beginning of more than half the number of students do not have a high interest in writing proposals. From the results of the interaction and analysis of questionnaire data obtained several reasons which in general are the lack of knowledge and ability to pour the contents of the mind in writing. Students prefer to pour their thoughts in the form of presentations. Students do not feel the need to write if they do not face a thesis, even though there are enough opportunities for students to show their thinking creativity in student creativity research held every year.

At the second meeting,students were given basic material on research. Routine assignments that are given only to work on LK are given during learning activities. To encourage making the initial draft the proposal is given the assignment of Critical Journal Review. Through this assignment students are asked to look for 5 journals related to general problem variables in learning. From this CJR, students are asked to analyze problems that often occur in the classroom supported by experience when students do internship I and internship II. Students are given the opportunity to take 1 week to complete their assignments. At this stage students identify, choose and formulate problems.

At the third meeting, discussions were carried out on the results of the CJR assignments. Departing from the problems obtained by students, students were asked to find a way out of the problems they found. And this is part of the development of the Rekaya Ide assignment. Students are given one week to work on engineering ideas. At this stage students form the mindset of the problems found and formulate hypotheses.

At the fourth meeting, an evaluation was carried out from the previous assignment. By continuing to connect between CJR and RI duties, students are encouraged to find literature literature from the previous discussion of CJR and RI. This assignment is stated in the Critical Book Review (CBR) assisgnment.

At the fifth meeting, an evaluation of the previous assignment assignments, CJR, RI and CBR was conducted again. The lecture material is still provided during the meeting so it does not miss the basic knowledge material that must be possessed in writing a research proposal. From the results of the assignments obtained from the 4 previous meetings students were asked to summarize all findings into a research proposal. The research proposal consists of introduction, literature review and research methods.

At the sixth meeting, an evaluation of the previous assignment was still carried out. at this meeting students were given a questionnaire to see interest in writing. The following results are obtained:

Table 2. Interest Questinnare results I

\begin{tabular}{ccc}
\hline Interest critria & $\mathbf{f}$ & $\%$ \\
\hline Very high & 6 & 20 \\
High & 18 & 60 \\
Sufficient & 5 & 16,6 \\
Low & 1 & 3,3 \\
Very low & 0 & 0 \\
\hline
\end{tabular}

Overall results for six weeks may change. At the initial meeting the number of students who had high interest in writing a research proposal was only (9 persom) 30\%. after going through the program by developing program assignments in the KKNI, especially on the 
assignments of CJR, CBR and RI. It appears that the number of students who have high interest in writing research proposals to be 24 person or $80 \%$. From the results of the interaction as the process of the previous meeting, students with the relevance of the assignments of CJR, CBR and RI, they were easier in pouring context and creative ideas into writing forms as a proposal from the research.

\section{Conclusions}

Through the development and synergy of the 6 KKNI assignments, namely collaboration between CJR, CBR and RI assignments can increase students' interest in writing educational research proposals.

From the results of the questionnaire calculation in the beginning only 9 person $(30 \%)$ students had a high interest in writing a research proposal. At the end of the meeting 6 questionnaire analysis showed an increase in interest to 24 person $(80 \%)$.With the synergy of 3 KKNI assignments, it is easier for students to write proposals.

The weaknesses in the results of this study are because this research is a preliminary study from another study, not all KKNI assignments are integrated. the reason is that the next stage is still needed so that the implementation of the research proposal is done through the synergy of the Mini Research and Project assignments. In addition, in short the study time, research proposals made by students were not too maximal. It was found that there were still many students who had not followed the procedure to write a research proposal. So far it is good enough as long as students are motivated to write which is the basic capital in being a potential human resource.

\section{References}

[1] Akhadiah, etc.,Coaching Indonesian Language Ability, Publish Erlangga, Jakarta. (2003)

[2] Dokumen 001. Kerangka Kualifikasi Nasional Indonesia (KKNI). Kementrian Ristek, Teknologi, dan Pendidikan Tinggi. (2015)

[3] HasnunPractical Guidelines and Instructions for Writing, Yogyakarta. (2014)

[4] Nazir, Moh. Research Method, Publish Ghalia, Indonesia. (2011)

[5] Narbuko, etc. Metodologi Penelitian. Jakarta : Bumi Aksara.(2012)

[6] RudiSalam,etc. Peningkatan Kualitas Publikasi Ilmiah dalam Menunjang Daya Saing Perguruan Tinggi, Jurnal Office Vol. 3 No 1 Januari-juni 2017. (2017)

[7] Rahmiati, Analysis of Internal Obstacles of Students in Writing Scientific Work, Journal AlDaulah Vol.3 No. 2. (2014)

[8] Rahayu, Indonesian Language in Higher Education, Publish Gramedia Widiasarana, Indonesia. (2007)

[9] Sandjaja, B., Albertus Heriyanto, Panduan Penelitian. Jakarta: Prestasi Pustakaraya. (2011)

[10] Susanto, Happy., Panduan Lengkap Menyusun Proposal, Visimedia, Jakarta. (2010)

[11] Suryana., Research Methodology, Textbooks Universitas Pendidkan indonesia. (2010)

[12] Sukmadinata, Metode Penelitian Kualitatif Pendidikan. Rosda Karya, Bandung. (2006)

[13] Tiur, M. S., Suci, F., Development of Teaching Book Based on KKNI, International Journal of science and Research (IJSR) . (2017)

[14] Tri, E., etc., Development of KKNI Oriented Learning Tools on Islamic Economics courses, Jurnal Niagawan Vol.7. (2018)

[15] Winataputra,U,S., Teaching and Learning Strategies,PublishUniversitas Terbuka, Jakarta. (2003) 